\title{
Tata Laksana Perawatan Ulkus Traumatik pada Pasien Oklusi Traumatik: Laporan Kasus
}

\author{
Bayu V. Violeta, ${ }^{1,2}$ Bambang T. Hartomo ${ }^{1.2}$
}

\author{
${ }^{1}$ Jurusan Kedokteran Gigi, Fakultas Kedokteran, Universitas Jenderal Soedirman, Purwokerto, \\ Jawa Tengah \\ ${ }^{2}$ Rumah Sakit Gigi dan Mulut Unsoed, Universitas Jenderal Soedirman, Purwokerto, Jawa \\ Tengah \\ Email: bambang.hartomo@unsoed.ac.id
}

\begin{abstract}
Traumatic oral ulcer is commonly caused by mucosal injury due to mastication or speaking, warm food or drink, sharp restoration surface, as well as partial broken restored tooth. We reported a case of traumatic oral ulcer in an 18-year-old female who was admitted to the RSGM Unsoed due to painfull sensation on the lesion. Objective examination revealed two lesions, as follows: tooth 47, painfull ulcer in buccal mucosa, solitary, whitish red, white border (punch-out), $4 \mathrm{~mm}$ in diameter; teeth 33 and 34, an irregular fissure, solitary, on the $2 / 3$ posterior part of the tongue, $2 \mathrm{~mm}$ in depth, $1 \mathrm{~cm}$ in length, and not painfull. The diagnosis of this case was traumatic ulcer due to traumatic occlusion based on anamnesis, examination, and occlusion check using articulating paper on the nearest antagonistic tooth to the lesion. The treatment included Dental Health Education (DHE) concerning proper tooth brushing, topical triamcinolone acetonide application for 5 days, dan selective grinding of teeth 17 and 47 . After oneweek follow-up, the ulcer had improved and no hyperemia, therefore, the patient could chew comfortably.
\end{abstract}

Keywords: traumatic ulcer, traumatic occlusion, selective tooth grinding

\begin{abstract}
Abstrak: Ulkus traumatik biasanya disebabkan oleh tergigitnya dinding mukosa ketika makan atau berbicara, meminum dan memakan yang panas, permukaan restorasi gigi yang tajam, maupun adanya tumpatan yang pecah sebagian. Kami melaporkan kasus seorang perempuan berusia 18 tahun dengan kondisi ulkus traumatik datang ke RSGM Unsoed karena merasa terganggu dan perih pada bagian yang luka. Pada pemeriksaan objektif didapatkan pada gigi 47 , lesi berupa ulkus pada area mukosa bukal, tunggal, berwarna merah keputihan, dengan peninggian pada tepi berwarna putih, nyeri, diameter $4 \mathrm{~mm}$; dan pada gigi 33 dan 34, lesi berupa fisura memanjang, berbentuk iregular, tunggal, pada $2 / 3$ dorsum lidah dengan kedalaman $2 \mathrm{~mm}$, panjang $1 \mathrm{~cm}$, tidak terasa nyeri. Diagnosis kasus ini ialah ulkus traumatik akibat oklusi traumatik berdasarkan anamnesis, pemeriksaan, dan cek oklusi menggunakan articulating paper pada gigi antagonis terdekat dengan lesi. Penatalaksanaan meliputi Dental Health Education (DHE) yaitu cara sikat gigi yang baik dan benar, pemberian triamcinolone acetonide topical selama 5 hari, dan selective grinding pada gigi 17 dan 47. Setelah satu minggu pada pengecekan didapatkan perbaikan ulkus dan tidak ditemukan pembengkakan sehingga pasien sudah nyaman untuk makan pada area tersebut.
\end{abstract}

Kata kunci: ulkus traumatik, oklusi traumatik, selective grinding, trauma mekanik

\section{PENDAHULUAN}

Sariawan atau ulkus banyak ditemukan dalam kehidupan sehari-hari. Umumnya lesi ulkus terasa nyeri serta mengganggu dalam proses mastikasi dan fonasi. Terganggunya fungsi mastikasi dan fonasi dapat memengaruhi kehidupan sosial dan terganggunya penyerapan dari zat gizi 
sehari-hari. Lesi dari ulkus biasanya terasa nyeri karena hilangnya permukaan jaringan epitel pada suatu jaringan lunak dalam mulut, yang akan memengaruhi aspek stomatognasi. Tata laksana ulkus yang tepat sangat diperlukan untuk pengobatan yang optimal. ${ }^{1}$

Ulkus dapat disebabkan oleh trauma fisik berupa tergigit, adanya permukaan gigi yang tajam akibat karies, tepian restorasi yang tajam karena kurang baiknya finishing polishing, tumpatan yang pecah, memakan makanan yang masih panas, reccurent aphtous stomatitis, trauma kimia seperti aspirin burn, serta kekurangan zat besi, vitamin B12, dan asam folat. ${ }^{2}$

Penegakan diagnosis ulkus yang tepat dapat mempermudah tenaga kesehatan dalam pemberian terapi yang sesuai sehingga meminimalkan ulkus agar tidak berkembang menjadi semakin parah. Lesi ulkus traumatik dapat sembuh dengan sendirinya dalam waktu 10 hingga 14 hari apabila iritan atau penyebab dihilangkan karena dalam rentang waktu tersebut akan terjadi proses keratinisasi dan pembaharuan sel-sel epitel mukosa oral. ${ }^{3}$ Penanganan ulkus traumatik yang utama ialah menghilangkan penyebab trauma dan pemberian obat antiinflamasi, seperti kortikosteroid topikal dan intralesi, juga anastetikum lokal. ${ }^{2}$

Mengingat kejadian ulkus traumatik sering ditemukan dalam praktek sehari-hari maka penulis tertarik untuk membahas mengenai penyebab, tanda dan gejala, penampakan klinis, serta tatalaksana ulkus traumatik pada seorang pasien yang mengalami oklusi traumatik di RSGMP Universitas Jalan Sudirman (UNSOED) Purwokerto.

\section{LAPORAN KASUS}

Seorang pasien IN, berusia 18 tahun, jenis kelamin perempuan, berobat ke RSGMP UNSOED tanggal 3 November 2016 dengan keluhan utama adanya sariawan yang telah diderita selama lima hari. Pasien datang ke RSGMP UNSOED seminggu yang lalu untuk dilakukan pembersihan karang gigi. Pada pemeriksaan subjektif didapatkan keadaan umum pasien kompos mentis, BB $43 \mathrm{~kg}$, TB $155 \mathrm{~cm}$, tekanan darah $110 / 80 \mathrm{~mm} \mathrm{Hg}$, nadi 70x/menit, pernapasan 20x/menit, dan suhu badan $36^{\circ} \mathrm{C}$. Past medical history dan social history tidak ada kelainan.

Pada pemeriksaan objektif diperoleh pada gigi 47: terdapat lesi berupa ulkus pada area mukosa bukal, lesi tunggal berwarna merah keputihan dengan tepi meninggi berwarna putih, nyeri, diameter 4 mm; pada gigi 33 dan 34, terdapat lesi berupa fisura memanjang, berbentuk iregular, lesi tunggal pada $2 / 3$ dorsum lidah dengan kedalaman $2 \mathrm{~mm}$ dan panjang 1 $\mathrm{cm}$, tidak terasa nyeri (Gambar 1).

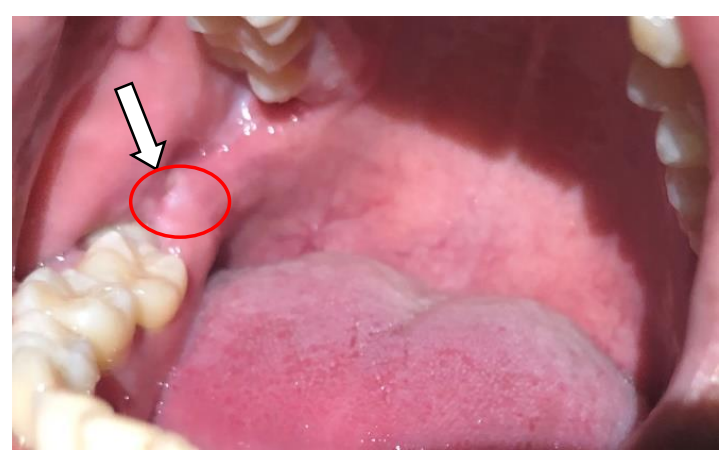

Gambar 1. Ulkus traumatik pada pasien

Cek oklusi dilakukan dengan menggunakan articulating paper pada gigi antagonis terdekat. Berdasarkan anamnesis, letak lesi, dan hasil cek oklusi maka pasien ini didiagnosis sebagai ulkus traumastik et causa oklusi traumatik. Sebagai diagnosis banding kasus ini ialah stomatitis aphtosa rekuren (SAR). Pasien menyangkal adanya stres akademik ataupun pribadi sehingga dapat disimpulkan bahwa diagnosis SAR dapat disingkirkan.

Perawatan yang dilakukan pada pasien ini ialah Dental Health Education (DHE) meliputi cara sikat gigi yang baik dan benar, terapi medikamentosa seperti pemberian triamcinolone acetonide selama 5 hari, dan dilakukan selective grinding pada gigi 17 dan 47. Setelah satu minggu kemudian dilakukan kontrol untuk pengecekan pada luka ulkus traumatik dan gigi yang dilakukan selective grinding dan didapatkan telah terjadi perbaikan serta tidak ditemukan pembengkakan. Pasien sudah 
nyaman untuk makan pada area tersebut. Area selective grinding gigi 17 dan 47 dilakukan evaluasi berupa pengecekan permukaan yang tajam dan kasar menggunakan articulating paper, serta finishing dan polishing ulang pada permukaan yang masih kasar.

\section{BAHASAN}

Ulkus traumatik yang disebabkan oleh trauma mekanik dapat diakibatkan oleh kontak gigi yang melukai bagian gusi, makanan berstruktur tajam, serta tergigitnya jaringan lunak rongga mulut pada saat makan atau berbicara. ${ }^{4}$ Ulkus traumatik yang disebabkan oleh trauma kimiawi dapat diakibatkan oleh prosedur pada kedokteran gigi berupa pengaplikasian bahan tinggi asam seperti etsa, bonding, obat sterilisasi pada perawatan saluran akar seperti formokresol dan paraformaldehid. Lesi ulkus traumatik dapat juga terjadi akibat penggunaan chlorhexidine gluconate dan aspirin bubuk yang digunakan sendiri oleh pasien ke dalam kavitas gigi yang tentunya tidak sesuai dengan standar perawatan kedokteran gigi dan mulut. ${ }^{5}$

Pada kasus ini, pemeriksaan objektif memperlihatkan adanya lesi pada area mukosa bukal gigi 47 dan fisura pada area gigi 33 dan 34 . Terjadinya ulkus traumatik diakibatkan oleh oklusi traumatik antara gigi 17 dan 47 yang mengenai mukosa. Kondisi gigitan terbalik memperparah terjadinya ulkus traumatik pada pasien tersebut karena gigi antagonis tidak mengenai gigi melainkan mengenai mukosa sehingga menimbulkan lesi ulkus traumatik yang berulang. Lesi pada rongga mulut dapat menjadi salah satu penyebab dari adanya penyakit sistemik, namun infeksi yang dihasilkan dapat pula dijadikan penyebab oleh faktor lokal seperti trauma.

Terdapat banyak trauma yang dapat menyebabkan ulkus yaitu antara lain trauma mekanik, trauma termal, dan trauma kimia. ${ }^{6}$ Gambaran klinis ulkus traumatik akibat trauma mekanik bervariasi, sesuai dengan intensitas dan ukuran dari penyebabnya. Biasanya gambaran klinis ulkus traumatik berupa lesi ulkus tunggal yang berbentuk oval dan cekung. Bagian tengah ulkus berwarna kuning ke abu-abuan atau putih keabu-abuan dengan bagian pinggir terdapat kemerahan. Permukaan lesi halus dan pada palpasi lunak serta bentuk lesi tidak teratur. Ukuran lesi biasanya 1-8 mm, selain itu ukuran lesi juga dapat bervariasi dan tergantung trauma yang menjadi penyebab. Lokasi lesi terdapat di bagian tepi lidah, mukosa bukal, mukosa dalam bibir, gingiva, dan bagian palatum. Lesi yang disebabkan oleh trauma karena tekanan gigi tiruan sering terletak pada tepi plat gigi tiruan. ${ }^{7}$ Pada kasus ini, lesi terdapat pada area mukosa bukal gigi 47, lesi tunggal berwarna merah keputihan dengan tepi meninggi berwarna putih, dan terasa nyeri. Juga terdapat lesi berupa fisura memanjang, berbentuk iregular, lesi tunggal pada $2 / 3$ dorsum lidah yang tidak terasa nyeri. Lokasi, bentuk, dan karakteristik lesi pada kasus ini berserta hasil anamnesis mendalam yang dilakukan menyokong diagnosis ulkus traumatik et causa oklusi traumatik.

Ulkus traumatik pada pasien dengan oklusi traumatik terjadi karena trauma pada mukosa yang dapat menimbulkan luka. Luka yang terbuka mengakibatkan terjadinya inflamasi sehingga memerlukan proses kompleks untuk dapat kembali sembuh. Proses penyembuhan luka melewati empat tahap yaitu hemostasis, inflamasi, proliferasi, dan remodeling. Inflamasi merupakan respon tubuh yang bertujuan proteksi untuk menghalangi dan menghilangkan penyebab serta membuang sel dan jaringan nekrotik pada luka. ${ }^{8}$ Makrofag memegang peranan penting dalam penyembuhan luka. Sel-sel ini melakukan fagositosis bakteri yang telah mengalami nekrosis, dan menyekresi sitokin dan mediator proinflamasi seperti interleukin-1 (IL-1), inter-leukin-6 (IL6), dan tumor necrosis factor- $\alpha$ (TNFa). ${ }^{7}$ Makrofag muncul pada 48-96 jam setelah terjadinya perlukaan serta dapat mempercepat fase inflamasi ke fase proliferasi. Proses ini dilakukan dengan memroduksi Growth Factor- $\beta$ (TGF $\beta$ ), Vascular Endothelial Growth Factor (VEGF), dan Fibroblast Growth Factor (FGF) sehingga proses penyembuhan dapat dilanjutkan dan 
dipercepat. Pada hari ketujuh setelah terjadi luka, jumlah makrofag mulai menurun karena fase inflamasi sudah berakhir dan memasuki fase proliferasi. ${ }^{8}$

Terdapat berbagai tindakan medikamentosa yang sering digunakan untuk mengatasi gejala akibat ulkus traumatik. Pengobatan yang dilakukan dapat bervariasi tergantung dari factor pemicu terjadinya ulkus. Prinsip dasar pengobatan penyakit mulut ialah dengan memberikan pengobatan secara simtomatik, mulai dari pemberian obat yang mengandung anestetikum hingga kortikosteroid. Manfaat pengobatan tersebut ialah mengurangi reaksi inflamasi yang akan muncul sehingga proses penyembuhan dapat terjadi lebih cepat. $^{3}$ Gejala yang sering ditemukan berupa adanya rasa nyeri pada permukaan ulkus, sensasi terbakar dan terasa perih, serta nyeri saat berbicara, mengunyah dan menelan. Sediaan yang dipakai pada ulkus biasanya berupa salep atau gel yang memberikan sensasi sejuk dan menyelimuti bagian yang terbuka. Sensasi sejuk yang diberikan biasanya didapat dari bahan alami yaitu ekstrak aloe vera yang dapat ditambahkan pada komposisi gel untuk obat ulkus traumatik. Prinsip dasar penggunaan medikamentosa seperti covering agent ialah pengobatan lesi yang dianggap penting untuk membantu menghilangkan gejala yang muncul karena lesi terselimuti oleh segala iritan. ${ }^{1}$

Pemilihan perawatan pada kasus ini meliputi pemberian terapi medikamentosa berupa triamcinolone acetonide untuk mengurangi peradangan dan kemerahan. Pemilihan triamcinolone acetonide dikarenakan obat ini merupakan kortikosteroid yang mempunyai efek mengurangi tanda dan gejala inflamasi pada mukosa oral. Penggunaan salep ataupun gel triamcinolone acetonide dilakukan dengan mengoleskannya pada ulkus yang telah dikeringkan sesaat setelah makan setiap 8 jam sekali selama 5 hari.

Evaluasi kasus dilakukan selama satu minggu. Setelah keadaan ulkus membaik dilakukan selective grinding pada tonjol yang bermasalah. Seminggu kemudian dila- kukan kontrol berupa pengecekan pada luka ulkus traumatik dan gigi yang dilakukan selective grinding. Pada kasus ini evaluasi di hari ke-7 menunjukkan terjadinya perbaikan dan tidak ditemukan pembengkakan lagi sehingga pasien sudah nyaman untuk makan pada area tersebut. Area selective grinding gigi 17 dan 47 dilakukan pengecekan permukaan yang tajam dan kasar menggunakan articulating paper, finishing dan polishing ulang pada permukaan yang masih kasar. Kasus prematur kontak terjadi di antara gigi rahang atas dan gigi rahang bawah dapat menimbulkan ulkus traumatik.

Perawatan selective grinding dilakukan dengan cara mengurangi bagian tonjol dan lereng yang menyebabkan trauma. Tatalaksana selective grinding dikenal dengan istilah BULL (Buccal Upper Lingual Lower) dan MUDL (Mesial Upper Distal Lower) yang menjadi acuan untuk mengurangi gigi yang mengalami premature kontak. Perawatan selective grinding merupakan perawatan yang sangat tepat untuk penanganan kasus traumatik oklusi. ${ }^{9}$

Sebagai diagnosis banding ialah stomatitis apthous rekuren (SAR), mayor apthous ulcer, ulkus herpertiform, Behcet's syndrome, dan infeksi herpes simplex virus (HSV). Perbedaan gambaran klinis ulkus traumatik dengan SAR ialah SAR lebih banyak ditemukan pada rongga mulut dibandingkan ulkus traumatik. Hal ini berdasarkan riwayat terjadinya dan gambaran klinis lesi. Lesi SAR biasanya ditandai dengan adanya tepi teratur dan dikelilingi daerah kemerahan serta dasar lesi ditutupi oleh fibrin berwarna putih kekuningan, terjadi akibat adanya trauma atau dengan faktor lain dan melibatkan mediator kimia/sitokin sehingga memicu terjadinya reaksi imunologik yang berujung pada rusaknya epitel mukosa, sedangkan ulkus traumatik terjadi bila epitel mukosa mulut rusak akibat adanya jejas akut dan hanya akan melibatkan sel-sel inflamasi akut dengan gambaran klinis terlihat tepi lesi yang tidak jelas. ${ }^{1}$ Pada SAR terdapat riwayat ulkus yang berulang di mukosa oral pasien tetapi tidak memiliki gejala penyakit 
lain. Lesi SAR dapat muncul secara berulang baik sebagai lesi tunggal ataupun lesi dengan jumlah banyak. Selain itu, SAR sering terjadi pada mukosa mulut yang tidak berkeratin, palatum lunak, mukosa pada bagian bukal, pada dasar mulut dan juga lidah. ${ }^{10}$ Faktor yang berperan pada timbulnya lesi SAR antara lain hormonal, stres, herediter, infeksi bakteri dan virus, psikologis atau emosi, reaksi hipersensitivitas atau alergi, defisiensi zat besi, asam folat, dan gangguan sistem imun. Pada kasus ini, pasien menyangkal adanya stres akademik ataupun pribadi serta tidak terdapat riwayat terjadinya ulkus yang rekuren, sehingga dapat disimpulkan bahwa diagnosis untuk kasus ini bukan SAR. Walaupun stres dapat menimbulkan SAR karena adanya ketidakstabilan hormon, tetapi peran hormon bukanlah faktor utama terjadinya SAR melainkan sebagai faktor predisposisi yang memperparah terjadinya suatu penyakit. ${ }^{1,11}$

Diagnosis banding lainnya ialah Behcet's syndrome yang mempunyai manifestasi klinis berupa adanya lesi ulkus pada 3 daerah yaitu daerah mata, rongga mulut, dan kelamin. Lesi ulkus pada rongga mulut merupakan lesi yang paling sering dijumpai. Manifestasi klinis ulkus berupa sekelompok mirip lesi apthous, bisa terdapat pada area di rongga mulut, namun ciri yang khas ialah terjadi lesi pada mukosa bibir atau pipi. Ulkus pada Behcet's syndrome berbentuk oval, rata, dengan ukuran bervariasi ${ }^{10}$ yang tidak sesuai dengan kasus ini.

Penampakan klinis infeksi lesi herpes simplex virus (HSV) mirip dengan lesi SAR tipe herpetiform, diawali adanya lesi vesikobulosa yang disertai dengan keluhan perih, sensasi terbakar dan gatal. Hal yang membedakan infeksi HSV dengan SAR ialah pada kasus HSV hanya terjadi pada mukosa tanpa keratin. Selain itu, pasien dengan infeksi virus biasanya didahului dengan gejala prodromal atau flu-like syndrome seperti demam dan malaise ${ }^{10}$ yang tidak dijumpai pada pasien ini.

Penatalaksanaan terapi ulkus traumatik berupa terapi penghilangan faktor etiologi atau penyebab (trauma) dan tergantung pada ukuran, lama, dan lokasi lesi. Terapi berupa pemberian obat kumur antiseptik seperti povidoniodine $1 \%$ dan chlorhexidine gluconate $0,2 \%$. Antibiotik seperti penisilin diberikan untuk mencegah infeksi sekunder, khususnya jika lesi dalam dan parah, namun hal ini jarang dilakukan. Medikasi berupa pemberian gel triamcinolone acetonide (Kenalog) dan vitamin $\mathrm{C}$ lebih sering diberikan untuk pasien dengan ulkus traumatik. ${ }^{7}$ Terapi suportif dapat dilakukan dengan cara diet lunak. Jika lesi mencapai jaringan ikat maka ulkus akan sembuh dalam waktu 1 sampai 2 minggu. Pada setiap ulkus yang menetap melebihi 2 minggu, harus dilakukan tindakan biopsi untuk menentukan apakah ulkus tersebut merupakan suatu keganasan. ${ }^{10}$

Terapi medikamentosa yang efektif dalam tatalaksana ulkus traumatik pada pasien oklusi traumatik sangat beragam. Salah satu obat yang dapat menjadi pilihan ialah penggunaan tablet hisap vitamin $\mathrm{C}$, obat kumur chlorhexidine gluconate 0,2\%, obat kumur antibiotika (larutan tetrasiklin 2\%), salep asam hialuronat ( $\mathrm{AH})$, dan steroid topikal. Asam hialuronat merupakan matriks ekstrasel yang dihasilkan tubuh saat terjadi inflamasi akibat jejas jaringan, dan komponen ini merupakan salah satu pengikat yang berfungsi untuk meredakan peradangan. Pemberian sediaan asam hialuronat gel pada lesi dapat mengurangi peradangan yang terjadi sesegera mungkin teratasi. Gel dengan kandungan aktif $\mathrm{AH}$ banyak dipakai dan memberikan efek baik selama rentang waktu pemakaian berkisar 5-8 hari tergantung dari jenis dan ketelatenan pasien dalam memakai obat teratur. Sejauh ini gel AH tidak memiliki efek samping secara sistemik sehingga dapat dijadikan salah satu pilihan obat topikal. ${ }^{12}$ Pengurangan tonjol dan lereng pada perawatan selective grinding mampu mengeliminasi penyebab utama pada kasus ulkus traumatik yang disebabkan oleh oklusi traumatik.

Perawatan yang dilakukan pada kasus ini telah sesuai standar operasional prosedur (SOP) yang dilakukan oleh tenaga kesehatan. Penggunaan triamcinolone ace- 
tonide $0,1 \%$ secara topikal pada rongga mulut memiliki efek menghilangkan pembengkakan dan mengurangi rasa nyeri. ${ }^{11}$ Pemberian triamcinolone acetonide 0,1\% dan multivitamin efektif mengurangi rasa nyeri dan menyembuhkan ulkus pada hari ke $14 .{ }^{9}$ Perawatan yang dilakukan pada pasien ini adalah Dental Health Education (DHE) meliputi cara sikat gigi yang baik dan benar, terapi medikamentosa seperti pemberian triamcinolone acetonide selama 5 hari, dan dilakukan selective grinding pada gigi 17 dan 47. Perawatan selective grinding pada ulkus traumatik ialah menghilangkan beberapa bagian tonjol atau melandaikan bagian fisura dengan menggunakan handpiece dan bur. ${ }^{13}$ Penggunaan perawatan selective grinding efektif untuk eliminasi trauma dan meningkatkan penyembuhan luka. ${ }^{14}$

\section{SIMPULAN}

Telah dilaporkan sebuah kasus ulkus traumatik et causa oklusi traumatik pada seorang perempuan berusia 18 tahun. Diagnosis ditegakkan berdasarkan anamnesis, tanda dan gejala klinis, serta pemeriksaan. Penatalaksanaan yang dilakukan ialah Dental Health Education (DHE) meliputi cara sikat gigi yang baik dan benar, terapi medikamentosa pemberian triamcinolone acetonide topikal selama 5 hari, dan selective grinding pada gigi 17 dan 47 . Evaluasi pada hari ke 7 memperlihatkan terjadinya perbaikan ulkus dan tidak ditemukan pembengkakan sehingga pasien sudah nyaman untuk makan pada area tersebut.

Etiologi terjadinya ulkus sangat kompleks sehingga penegakan diagnosis untuk kasus ulkus harus dilakukan dengan seksama agar perawatan yang dilakukan dapat optimal. Pengoptimalan diagnosis dapat melalui berbagai cara yaitu dengan menggunakan test laboratorium untuk memeriksa adanya kemungkinan penyebab lain terjadinya ulkus. Selain itu dibutuhkan penelitian lanjutan untuk mengetahui secara pasti faktor pencetus terjadinya ulkus traumatik, dan juga mengenai berbagai bahan medikamentosa lainnya untuk melebarkan spektrum pengobatan sesuai dengan kebutuhan pasien

\section{Konflik Kepentingan}

Penulis menyatakan tidak terdapat konflik kepentingan dalam studi ini.

\section{DAFTAR PUSTAKA}

1. Amtha R, Marcia AIA. Plester sariawan efektif dalam mempercepat penyembuhan stomatitis aftosa rekuren dan ulkus traumatikus. Majalah Kedokteran Gigi Indonesia. 2017;3(2):17-9.

2. Herawati E, Dwiarie TA. Temuan klinis dan manajemen kasus ulserasi rongga mulut terkat trauma iatrogenic. J. Ked Gi Unpad. 2019;31(2):102-7.

3. Sunarjo L, Hendari R, Rimbyastuti H. Manfaat xanthone terhadap kesembuhan ulkus rongga mulut dilihat dari jumlah sel PMN dan fibroblast. Odonto Dental Journal. 2015;2(2):14-21.

4. Mortazavi H, Safi Y, Rahmani S. Diagnostic features of common oral ulcusative lesions: an updated decision tree. Int $\mathbf{J}$ Dent. 2016;14:(2):112-4.

5. Gilvetti C, Porter SR, Fedele S. Traumatic chemical oral ulceration: A case report and review of the literature. Br Dent J. 2010;208(7):297-300.

6. Girish AL, Chandra P, Nandlal B, Srilatha K. 2015 Iatrogenic injury of oral mucosa due to chemicals: a case report of formocresol injury and review. $\mathrm{J} \mathrm{Br}$ Dent. 2015;208(7):297-300.

7. Khairiati MW, Bakar A. Ulkus traumatikus disebabkan trauma mekanik dari sayap gigi tiruan lengkap (laporan kasus). Jurnal B-Dent. 2014;1:(2):112 -7.

8. Rahmawati A, Pargaputri AF, Karsini IS. Pengaruh pemberian ekstrak alga coklat jenis Sargassum Sp. terhadap jumlah makrofag pada proses penyembuhan ulkus traumatikus. Denta. 2018;12(1): 72-8.

9. Sukmawati T, Gunawan L, Reginata G. Manifestasi klinis sindrom Behcet. CDK-245. 2016;43(10):756-9.

10. Ivhatry R, Rizky OPS. Ulkus traumatikus, scalloped tongue dan cheek biting [Laporan Studi Kasus Ilmu Penyakit Mulut]. Bandung: Universitas Padjadjaran; 2018.

11. Tarakji B, Gazal G, Al-Maweri SA, Azzeghaiby SN, Alaizari N. Guideline 
92 e-GiGi, Volume 8 Nomor 2, Juli-Desember 2020, hlm. 86-92

for the diagnosis and treatment of recurrent aphthous stomatitis for dental practitioners. Journal of International Oral Health 2015;7:(5):74-80.

12. Koray MO, Uoglu D, Senemtasi AS, Yaltirik M. The effecacy of hyaluronic acid gel in pain control of recurrent aphthous stomatitis. Int $\mathbf{J}$ Dentistry Oral Sci. 2016;3(6):273-5.

13. Florian M. Bite Adjustment (occlusal adjust- ment, spot grinding of hinge bite, occlusal equilibration [online]. 2020. Available from: https://yourdental specialist.com.au/bite-adjustment, web online 20-04-20.

14. Butt R, Aspinall AT. Restorative management of talon cusps: A case series. International Journal of Pediatric Dentistry. 2019;14:(2):112-4. 